\title{
Developing smokeless tobacco products for smokers: an examination of tobacco industry documents
}

\author{
C M Carpenter, ${ }^{1}$ G N Connolly, ${ }^{1} 0$ A Ayo-Yusuf, ${ }^{2}$ G Ferris Wayne ${ }^{1}$
}

${ }^{1}$ Harvard School of Public Health, Division of Public Health Practice, Boston,

Massachusetts, USA;

${ }^{2}$ Department of Community Dentistry, Faculty of Health Sciences, University of Pretoria, South Africa

\section{Correspondence to:}

Carrie M Carpenter, Harvard School of Public Health, Division of Public Health Practice, 401 Park Drive, Boston, MA 02215, USA; ccarpent@hsph.harvard. edu

Received 24 June 2008 Accepted 10 October 2008 Published Online First 23 October 2008

\author{
ABSTRACT \\ Objective: To investigate whether development of \\ smokeless tobacco products (SLT) is intended to target \\ current smokers.
}

Methods: This study analysed internal tobacco industry documents to describe research related to the smokeless tobacco market. Relevant documents included those detailing the development and targeting of SLT products with a particular emphasis on moist snuff.

Results: Cigarette and SLT manufacturers recognised that shifting demographics of SLT users, as well as indoor smoking restrictions, health concerns and reduced social acceptability of smoking could impact the growth of the SLT market. Manufacturers developed new SLT products to target cigarette smokers promoting dual cigarette and SLT use.

Conclusions: Heavy marketing of new SLT products may encourage dual use and result in unknown public health effects. SLT products have been designed to augment cigarette use and offset regulatory strategies such as clean indoor air laws. In the United States, the SLT strategy may provide cigarette companies with a diversified range of products under the prospect of federal regulation. These products may pose significant challenges to efforts by federal agencies to reduce harm caused by tobacco use.

Major cigarette manufacturers including RJ Reynolds, Philip Morris, Lorillard and British American Tobacco have recently made unprecedented moves into the smokeless tobacco (SLT) market, introducing traditional varieties of moist snuff and a new spitless form of SLT, called snus. While cigarette smoking and sales continue to decline in the US, moist snuff continues to grow in popularity, accounting for $71 \%$ of the US smokeless tobacco market in 2006. ${ }^{1}$ Moist snuff is administered orally and consists of finely ground tobacco distributed in loose form or in packets. Snus, or spitless moist snuff, is modelled after a Swedish tobacco product and has been introduced in the US more recently by smokeless and cigarette companies.

Cigarette manufacturers have developed new smokeless products, including moist snuff and snus brands, presented in attractive packaging and available in various flavours. Several of these new products carry the names and flavours of popular cigarette brands (for example, Camel, Lucky Strike, Marlboro). In 2006, Philip Morris (PM) introduced Marlboro Snus and Marlboro Snuff into test market, and RJ Reynolds (RJR) introduced Camel Snus in a number of US states.
This industry activity emulates a pattern seen in other countries. For example, British American Tobacco (BAT) is selling snus in Japan and South Africa also cross-branded with major cigarette brands (Peter Stuyvesant and Lucky Strike).

SLT manufacturers, such as US Smokeless Tobacco Company (USSTC), have also redesigned and marketed new SLT products. In 2001, USSTC introduced Revel, a smokeless, spitless product into test market. The recent introduction and marketing of SLT products, coupled with the rise in moist snuff sales and use, raises questions as to the tobacco industry's goals in developing and targeting these products.

An examination of internal documents can be used to better understand the cigarette industry's recent entry into the SLT market and identify the role of targeted SLT product development and marketing. Internal documents made available through litigation have informed an extensive body of evidence describing the industry's use of targeted product development to exploit specific smoker groups including youths, ${ }^{2}$ women, ${ }^{3}$ menthol smokers ${ }^{4}$ and psychological/psychosocial smoker groups. ${ }^{6}$ Research by Connolly utilised internal documents to describe how a major SLT company designed starter products to encourage experimentation and nicotine addiction among young new users through a "graduation" strategy (natural progression of product switching to higher nicotine brands). ${ }^{7}$ However, in general, research on the role of design and targeting of SLT products remains scant.

The purpose of this study was to review internal tobacco industry practices related to development, targeting and intended use of SLT products, particularly moist snuff and snus. Specifically, the objectives of the study were as follows: (1) to review the cigarette industry's objectives upon entry into the SLT market, (2) to examine research and marketing of SLT as a substitute or temporary complement to cigarette smoking; and (3) to examine product development of SLT products and targeting of smoker groups.

\section{METHODS}

Research was conducted through a web-based search of more than eight million internal tobacco industry documents made publicly available through the 1998 Master Settlement Agreement between the state attorneys general and major US tobacco manufacturers. Documents were retrieved from the archival databases maintained online at the British American Tobacco Documents Archive 
(www.bat.library.ucsf.edu), Legacy Tobacco Documents Library (legacy.library.ucsf.edu) and Tobacco Documents Online-US Smokeless Tobacco Company (USSTC) (www. tobaccodocuments.org). Documents were identified through an initial search of broad key terms (for example, smokeless tobacco, moist snuff, snus, product development, spitless, dualuse, target, cigarette smokers, taste, flavour, Marlboro, Camel) and combinations of these terms. Documents were identified through a snowball sampling method, initially using the set of broad key search terms described above and relevant combinations of these terms to then establish further search terms.

Relevancy was determined based on whether the documents described research related to the smokeless tobacco market, development and targeting of smokeless tobacco products with a particular emphasis on moist snuff products in general as well as the use of moist snuff to promote dual cigarette and SLT use (that is, "dual use") and target cigarette smokers. The study resulted in a final set of approximately 60 relevant documents, ranging in date between 1978 and 2006, including 44 documents cited here.

\section{RESULTS}

\section{Cigarette companies: entry into the SLT market}

As the cigarette market declines, SLT has emerged as an increasingly important market for cigarette companies. Cigarette manufacturers have monitored the SLT market closely highlighting potential growth opportunities. ${ }^{8-11}$ For example, in the early 1980s, BAT examined the possibility of entering into a joint business venture with USSTC in the production of SLT. A BAT report summarising an evaluation of the SLT market in the US and elsewhere described promising market opportunities stating: "Any product category which would allow us to sell the industry's basic product, tobacco, and its essential "USP" [unique selling point] (so far) nicotine satisfaction, as a "treat not a treatment" must be of interest". ${ }^{12}$ Likewise, a 1984 internal Philip Morris (PM) memo described the growth of the SLT market and an opportunity to enter into the industry through the acquisition of one of the major smokeless companies (USSTC, Conwood and Pinkerton). ${ }^{9}$ Despite established links between SLT and oral cancer, ${ }^{9}$ cigarette companies recognised that the SLT market would be less susceptible to litigation as well as health, social and regulatory pressure. When considering entry into the SLT market, BAT (1981) observed:

\footnotetext{
"Though not immune to health and social pressures and restrictions, if there was a fair chance it could fare less badly than would cigarettes or any form of smoking it might be a good bet to defend the industry and its basic product"..."Smokeless should be much easier to defend than smoking, but we would need to expect and prepare for further attacks once a "giant" like BAT is known to have made a major move in this direction". ${ }^{12}$
}

International markets also represented potential opportunities in expanding the SLT industry. In a 2001 analysis of the "Future Business Environment", BAT hypothesised that, in the future, the SLT and cigar industries would include " 3 to 5 global players". The report stated: "Longer term, the dedicated approach to new geographies will contribute in building demand and consumption of STC (smokeless tobacco and cigars) product categories in areas outside the EU and the US, which are generally under-developed

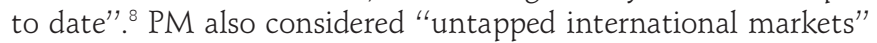
to be a possible growth area for the SLT market. ' In fact, PM posited that market entry outside of the US would be easier in terms of competition and resistance from USSTC. ${ }^{10}$

More recently, cigarette companies became particularly interested in the increased popularity of moist snuff..$^{10} 1213$ PM's 1993 analysis of the SLT industry reported that volume declines had occurred in every category of SLT with the exception of moist snuff. This report highlighted the predicted growth in the moist snuff category and discussed potential opportunities related to entry into this market. ${ }^{10}$

PM also noted that the predicted growth of the moist snuff market, particularly among white collar and urban users, could potentially increase the social acceptability of using snuff. ${ }^{9}$ PM's (1993) detailed summary of smokeless tobacco described that moist snuff users were "younger, better educated, less rural and have higher income than traditional smokeless tobacco product users". ${ }^{10}$ These demographic changes were considered important in terms of expanding the SLT market. RJR also studied moist snuff use among younger adult users (18-24 year olds) noting that this was the "largest and fastest growing age segment in the moist snuff category". ${ }^{13}$

\section{SLT for smokers: cigarette manufacturers}

Past interest in the SLT market has recently translated into major efforts to introduce snuff and snus products into the test and commercial market. Manufacturers have recognised that the rise in indoor smoking restrictions as well as smokingrelated health concerns and reduced social acceptability would hinder smoking rates, and, in turn, drive the future growth of the SLT market. Entry into this growing market offered cigarette manufacturers a means of offsetting losses occurring in the cigarette market, ${ }^{14}{ }^{15}$ as highlighted by internal industry quotes (table 1).

\section{Dual cigarette and SLT use}

Internal documents indicate that dual cigarette and SLT users, in particular, have been considered an important target group for moist snuff products. ${ }^{10} 1819$ In 1981, BAT described the possibility of SLT production:

\footnotetext{
"That such products could produce extra business, from the smokers who would otherwise quit or are unable (or unwilling) to smoke at certain times and places, from those currently taking nicotine in less palatable and acceptable smokeless forms, and from those who would not take up smoking, but could enjoy a smokeless product with nicotine satisfaction on its own merits". ${ }^{12}$
}

In 1993, PM's analysis of the smokeless tobacco industry concluded that young adult males (who choose moist snuff over loose leaf), college males (who choose snuff over cigarettes) and

Table 1 Industry quotes highlighting the use of SLT products in a changing cigarette market

BAT, no datedevelopment of a moist snuff product

PM, 1984-review of SLT market

RJR, 2003cigarette alternative project

RJR, 2003cigarette alternative project
"To capitalise on the potential downtrend of the smoking habit as the only means of achieving nicotine satisfaction by participating in a parallel product market which is free of social/health concerns, and with attractive profitability potential" ${ }^{\prime 16}$

"Future prohibitions against smoking in public places, work settings, etc, combined with increasing concern for the smoking and health issue, could provide an impetus for smokers to switch to an alternative product"

"Other sources concur, observing that increased bans on cigarette smoking should benefit the ST [smokeless tobacco] industry"17

"Is there likely to be a cigarette alternative category? Yes, bans and risk reduction will be drivers... It's difficult to be a smoker today"17 
converted or dual usage smokers were driving growth of the moist snuff market. ${ }^{10}$ At the same time, PM conducted a qualitative study to investigate smoking and non-smoking snuff users and to determine whether there were opportunities for new brands in this market. This study investigated the concept of Marlboro snuff. ${ }^{20}$ Results of this internal research showed that most smokers who expressed interest in trying SLT did not intend to switch completely but would be interested in using "snuff" when they were not able to smoke. ${ }^{20}$ Research results indicated that "Snuff usage among smokers is primarily for times when they can't smoke". ${ }^{20}$

When the concept of Marlboro snuff was explored in the early 1990s, PM found that snuff users expressed extreme brand loyalty. In fact, study participants expressed a stronger "user identity" with their snuff brand than that of typical smokers. ${ }^{20}$ Smoking snuff users felt that snuff could be used in situations when smoking was not possible (for example, restaurants, college classes, friends' homes or during work to free hands). However, the concept of a cigarette manufacturer entering the SLT market was generally not well received. ${ }^{21}$ Marlboro was considered the only plausible brand for snuff because it held the reputation of a "strong cigarette". ${ }^{20}$

RJR's (2003) qualitative research under Project MARS indicated potential interest in a smokeless, cigarette alternative among older, heavy smokers. This research indicated that an alternative offered several perceived benefits including a discreet way to satisfy craving, ease of anxiety, a necessary focus when unable to smoke and a method of getting smokers through times when smoking is not possible. ${ }^{17}$ These results also emphasised that product positioning and consumer education would be critical to product success, and described that:

\footnotetext{
"There is a need to clearly position the product as a situational substitute for cigarettes, rather than a

replacement...Communication of secondary benefits (e.g. no odor, no second-hand smoke) may help smokers rationalize the use of a product they would rather not admit they need". ${ }^{17}$
}

\section{SLT for smokers: SLT manufacturers}

While cigarette manufacturers have recently entered the SLT market to counteract losses in the cigarette market, SLT companies have aimed to capitalise on smoking-related health and social concerns and restrictions. ${ }^{17}$ Smoking alternatives for smokers facing public smoking restrictions and social pressure represented an important and promising growth opportunity for the SLT market. A 1992 USSTC document stated:

\footnotetext{
"the most likely new users are cigarette smokers who face lower social acceptance as smokers and more restrictions on when and where to smoke; some people may smoke less and use smokeless products like snuff because it is more discreet and not subject to bans. Also, some ex-smokers may compensate with smokeless products like snuff". ${ }^{22}$
}

USSTC recognised the need for "smoke-free" products because of increased indoor smoking restrictions noting that the litigation environment was less favourable for the cigarette industry than the SLT industry. ${ }^{19}$ In 2000, USSTC (located in RJR's collection) reported an increasing trend in dual usage of cigarettes and SLT (27\% in 1998 to 33\% in 1999) and attributed this change to rising indoor smoking restrictions as well as consumer perceptions of lower health risks associated with SLT. USSTC stated,
"In our view, the key opportunity is increasing moist smokeless tobacco usage among cigarette smokers (versus increasing market share among current users). There is obviously far more economic leverage in attracting current smokers to snuff, as opposed to increasing retention and/or usage among current snuff consumers". ${ }^{19}$

UST aimed to increase a sampling programme focused on current smokers and test market a "spitless" smokeless product in 2001. ${ }^{19}$

More recently, USSTC estimated expected gains in the moist smokeless market as a result of "conversion" (smokers using moist snuff as a socially acceptable alternative). In a 2003 presentation, USSTC asserted that "Conversion is Big Business" and recognised the potential to target smokers facing smoking restrictions. ${ }^{23}$

Cigarette manufacturers closely observed the SLT companies' interest in smokers. A 1989 PM memo states:

\begin{abstract}
"Until recently, industry experts (see attached) did not believe that cigarette smokers were converting to smokeless tobacco products, due to flavor and usage differences between cigarettes and snuff, plug, and looseleaf. However, some smokers are believed to be supplementing their cigarette smoking with smokeless tobacco. U.S. Tobacco, which already markets their Skoal Bandits as a tobacco option when cigarettes are inappropriate, may be envisioning an increase in this trend, in light of recent impositions of smoking restrictions and other social constraints." 24
\end{abstract}

\section{Development of SLT products for smokers Cigarette companies: SLT development}

The entrance of cigarette companies into the SLT market has resulted in the introduction of sophisticated moist snuff products designed to appeal to smokers. Internal documents reveal that smokeless, spitless tobacco products have historically been considered a long-term product goal ${ }^{25-30}$ and a potential means of delivering nicotine enjoyment in a socially acceptable way. ${ }^{25-29}$ In 1984, RJR noted: "Over time, the smokeless tobacco industry will likely evolve to new product forms and/or attributes that will better satisfy consumer wants for tobacco satisfaction and social acceptability." ${ }^{31}$ A BAT (1981) document stated:

"...mild, probably flavoured, snuff packed in sachets like miniteabags appears to be the most likely lead or starter product for the fastidious, hygiene-health orientated user who prefers discretion; perhaps for most beginners, certainly for females, and city dwellers. Convenience in use and disposal being a major benefit. $^{12}$

A number of research and development projects conceptualised and tested SLT products with unique taste and flavour characteristics (see table 2). Beginning in the 1980s, RJR pursued moist snuff products to compete with commercial SLT products such as Skoal and Copenhagen under Projects Wet Snuff-Skoal Type (WSS), Copenhagen Type Wet Snuff (WSC) and Wet Snuff Hawken (WSH). ${ }^{32-39}$ Under Project WSH, RJR aimed to develop a flavoured moist snuff product as a means of capitalising on a "consumer taste shift" towards flavoured products. $^{37}$

Manufacturers explored the application of novel technology in the development of SLT products. RJR (1981), for example, examined the use of "microencapsulation" in the development of SLT products including a colourless, spitless product designed for women. ${ }^{27}$ Gum-based technology was also considered a 
Table 2 Cigarette manufacturers SLT development projects

\begin{tabular}{|c|c|c|c|}
\hline Project name & Company, date & Goal & Product description \\
\hline $\begin{array}{l}\text { Project Visa-smokeless } \\
\text { tobacco }(\mathrm{eg}, \mathrm{snuff})^{40}\end{array}$ & BAT, 1988 & $\begin{array}{l}\text { Explore smokeless as nicotine } \\
\text { alternative product-may be useful in } \\
\text { terms of new ways of "smoking" }\end{array}$ & Smokeless tobacco-plug, snuff, etc \\
\hline $\begin{array}{l}\text { Project Specialty Tobacco } \\
\text { Products (STP) }\end{array}$ & RJR, 1983 & $\begin{array}{l}\text { Position RJR as a primary competitor } \\
\text { in the moist snuff tobacco market }\end{array}$ & $\begin{array}{l}\text { Dedicate resources to new moist snuff } \\
\text { brand under Project WSS/WSC }\end{array}$ \\
\hline Project WSH ${ }^{3536}$ & RJR, 1981 & $\begin{array}{l}\text { Compete with SLT products by } \\
\text { increasing tobacco satisfaction with } \\
\text { more tobacco taste, improve freshness } \\
\text { perception }\end{array}$ & $\begin{array}{l}\text { Flavoured prototypes tested among 18- } \\
34 \text { flavoured moist snuff users, results } \\
\text { showed further improvements } \\
\text { necessary }\end{array}$ \\
\hline Project WSS ${ }^{42}$ & RJR, 1983 & $\begin{array}{l}\text { Target skoal users, age } 18-34 \text {, blue } \\
\text { collar, high school educated males }\end{array}$ & $\begin{array}{l}\text { Wintergreen flavour smokeless } \\
\text { tobacco-“"Refreshing tobacco taste } \\
\text { that satisfies the active man" }\end{array}$ \\
\hline Project WSC ${ }^{42} 44$ & RJR, 1983 & Target Copenhagen users, $18-34$ & Natural flavoured smokeless product \\
\hline New Brand Development ${ }^{45}$ & Lorillard, 1978 & $\begin{array}{l}\text { Capitalise on market trends and } \\
\text { reassure smokers facing "smoking } \\
\text { controversy" }\end{array}$ & Snuff for cigarette smokers \\
\hline Project MARS ${ }^{17}$ & RJR, 2003 & $\begin{array}{l}\text { Develop a cigarette alternative that } \\
\text { delivers tobacco satisfaction for } \\
\text { smokers in situations when they } \\
\text { cannot or choose not to smoke }\end{array}$ & $\begin{array}{l}\text { Focus group research indicated interest } \\
\text { in a cigarette alternative especially } \\
\text { among heavy smokers and adult } \\
\text { smokers over } 30\end{array}$ \\
\hline
\end{tabular}

viable option for delivering tobacco through a spitless, nonnoticeable product that could serve as a socially acceptable means of enjoying tobacco. Targeting of this technology was planned for tobacco users including cigarette smokers and was considered "a key trend for future as anti-smoking forces attack the social acceptability and passive smoking issues". ${ }^{29}$ A 1980 RJ Reynolds document described long-term product design ideas including "a moist snuff type chewing product that provides tobacco/nicotine enjoyment but is spitless and holds together in mouth". ${ }^{25}$

Tobacco manufacturers have recently pursued innovative SLT product development as a key strategy in circumventing smoking legislation and targeting the "when you can't smoke" continuing smoker groups. Early product development efforts have been followed by the introduction of various moist snuff and snus products. For example, in 2006, RJR announced the test market for "a smokeless tobacco product that will come in a small pouch that is placed between the lip and gum" named Camel Snus. RJR pointed out that this product differed from other moist snuff products stating that it "does not require the consumer to spit-making it a convenient option for adult tobacco consumers". ${ }^{46}$ PM's new SLT product, Marlboro Snus, utilises a unique flavour strip.

\section{SLT companies: product development}

Targeting of smokers with SLT products has not been exclusive to cigarette companies. SLT manufacturers also have regarded smokers as an important market for new moist snuff and snus products. A 2003 USSTC business review of "moist smokeless tobacco" (MST) provided data showing that this distinct market was consistently growing and performing well against other packaged goods including cigarettes. USSTC estimated that $45 \%$ of smokers were interested in a socially acceptable alternative to cigarettes. ${ }^{23}$

This research was followed by extensive industry efforts to design SLT for smokers and non-traditional SLT users. In 2000, USSTC documented their plan to launch a "spitless" product designed for SLT consumers who considered spitting "distasteful". ${ }^{18}$ Revel was test marketed as an "Anytime, anywhere" product in 2001 and re-launched with mint and wintergreen flavours in 2003. ${ }^{17}$ In 2001, PM considered USSTC's Revel described as "snuff in tea bag-like pouches in various flavours and sizes; "spit-less" snuff" as a new product aimed at smokers and a competitive tobacco-related technology. ${ }^{47-49}$ PM (1989) were interested in product design changes within the SLT market noting:

"U.S. Tobacco and Pinkerton are introducing new varieties that will have more of a cigarette flavor, aimed at switching consumers from smokers to chewers. This comes at a time when smoking is banned in some work areas, so these brands will be targeted as cigarette alternatives". ${ }^{50}$

Internal documentation reveals that USSTC was interested in emulating the "Swedish model" which included key factors such as moving toward user-friendly pouch products and product variation and innovation as well as a "focus on diversified users (including women)". ${ }^{19}$ In 2001, SM aimed to increase snus sales in the US by introducing a spitless product, Exalt, with the "No smoking? No problem" marketing message. ${ }^{1751}$

\section{DISCUSSION}

Internal documents show that tobacco manufacturers, including cigarette and SLT companies, have developed and targeted new SLT products to exploit cigarette smokers. Cigarette manufacturers recognised the importance of entering the SLT market especially in light of health, social and legislative changes influencing the cigarette market and shifting demographics of traditional SLT users. Cigarette manufacturers were initially focused on developing alternative smokeless products for smokers who would otherwise quit because of the changes in the cigarette market. Over time, the cigarette companies appear to have focused their efforts on products designed to augment cigarette use when smoking is not possible, thus offsetting regulatory strategies such as clean indoor air laws.

Major cigarette companies' marketing of new SLT products under established brand names may be aimed at increasing the appeal of SLT to smokers, who are not necessarily interested in quitting smoking. At the same time, SLT companies have aimed to exploit smokers by promoting SLT as a cigarette alternative in the face of smoking restrictions. UST and SM have developed and marketed new, spitless SLT to appeal to smokers.

The introduction of new SLT products raises important questions with regard to the health risks associated with these 
products, particularly in light of the possibility that cigarette manufacturers are promoting combined cigarette and SLT use. Heavy marketing of SLT products to smokers by both industries may encourage dual use, and, thus, result in unknown and potentially harmful public health effects. Camel Snus marketing materials, for example, describe the product as "A tasty new tobacco pleasure for wherever" stating "You Can Snus virtually anywhere, from work to bars to trains to your fussy friend's party". Test markets for Camel Snus have included college communities. This corresponds with internal documents showing that college males were considered an important growth market for moist snuff. Further, college students are subject to campus and worksite smoking bans and may be enticed by the attractive marketing campaign.

The increased availability and use of SLT as a harm reduction method remains a controversial issue within the public health community. ${ }^{52}$ Although new SLT products contain lower levels of total carcinogens, these products still contain potentially harmful levels of toxicants including tobacco specific nitrosamines (TSNAs) and, thus, could result in adverse health consequences when used alone or as a smoking substitute. ${ }^{52} 53$ Assessment of internal SLT research may lead health researchers to an improved understanding of the possible role of SLT in maintaining tobacco dependence.

Nevertheless, the findings of this study should be considered in relation to the limitations associated with document-based research methodology. Internal documents disclose statements and conclusions from various authors representing various tobacco manufacturers that do not represent a complete set of documents. Additionally, the documents span a wide time period and do not represent a complete set of documents. In this study, documents were retrieved through 2006, which may not account for more recent developments in the tobacco market. Despite these limitations, document-based studies have contributed a wealth of important evidence to the published literature regarding internal industry research and practice.

Future studies should examine entry of tobacco manufacturers into the international SLT market, particularly in developing countries with limited tobacco control measures. In South Africa for instance, transnational tobacco companies have taken over production of traditional smokeless brands from local vendors, and simultaneously introduced SLT products cross-branded with major cigarette brands, such as Peter Stuyvesant and Lucky Strike. These products have been similarly promoted in that country as substitute for smoking where smoking is not allowed and the local subsidiaries of SM recently failed in an attempt to have snus exempted from the

\section{What this paper adds}

- Our study results show that tobacco manufacturers, including cigarette and SLT companies, have developed and targeted new SLT products to exploit cigarette smokers. These products have been designed to augment cigarette use when smoking is not possible, thus offsetting regulatory strategies such as clean indoor air laws.

- Heavy marketing of SLT products to smokers by both industries may encourage dual use and, thus, result in unknown and potentially harmful public health effects.

- Assessment of internal SLT research may lead health researchers to an improved understanding of the possible role of SLT in maintaining tobacco dependence. provisions of the regulation banning tobacco products advertisement and promotion. ${ }^{54}$

In the US, the introduction of these new SLT products designed as discrete, socially acceptable nicotine delivery alternatives may also represent a hedge against the future, as regulation of tobacco products by the US Food and Drug Administration (FDA) may result in a market more favourable to SLT than cigarettes. These potential market changes thus raise significant challenges to the development of effective policies by the FDA or other agencies to reduce harm from tobacco use. If the FDA is given regulatory authority over smokeless, action is needed to assure that products are not designed and promoted to perpetuate smoking.

Funding: This project was supported by grant number 5R01CA087477-08 from the National Cancer Institute.

Competing interests: None.

\section{REFERENCES}

1. Modi N. Q-series: moist smokeless tobacco: the next battleground for growth? UBS Investment Research 18 May 2007.

2. Wayne GF, Connolly GN. How cigarette design can affect youth initiation into smoking: Camel cigarettes 1983-93. Tob Control 2002;11(suppl):i32-9.

3. Carpenter CM, Ferris Wayne G, Connolly GN. Designing cigarettes for women: new findings for the tobacco industry documents, Addiction 2005;100:837-51.

4. Kreslake J, Ferris Wayne G, Connolly GN. The menthol smoker: tobacco industry research on consumer sensory perception of menthol cigarettes and its role in smoking behavior. Nicotine Tob Res 2008;10:705-15.

5. Kreslake JM, Ferris Wayne G, Alpert HR, et al. Tobacco industry control of menthol in cigarettes and targeting of youth and young adults. Am J Public Health 2008;98:1685-92.

6. Cook BL, Ferris Wayne G, Keithly L, et al. One size does not fit all: how the tobacco industry has altered cigarette design to target consumer groups with specific psychological and psychosocial needs. Addiction 2003;98:1547-61.

7. Connolly GN. The marketing of nicotine addiction by one oral snuff manufacturer. Tob Control 1995;4:73-9.

8. British American Tobacco. Future business environment 2001. http://bat.library. ucsf.edu/tid/qal55a99.

9. Long HP, Piskor SK. Smokeless tobacco. 4 May 1984. Philip Morris. Bates No 2040272649-2040272654. http://tobaccodocuments.org/pm/2040272649-2654.html (accessed 19 June 2008).

10. Lembo, L. Smokeless tobacco industry analysis. 25 Jun 1993. Philip Morris. Bates No 2046710489-2046710509. http://tobaccodocuments.org/pm/2046710489-0509. html (accessed 19 June 2008).

11. Philip Morris. Smokeless tobacco. (16 August 1989) Philip Morris. http://legacy. library.ucsf.edu/tid/dlk60b00.

12. Pearson. Smokeless tobacco. 1981. British American Tobacco. http://bat.library. ucsf.edu/tid/yku08a99.

13. Bellis JV. RJR younger adult users of moist snuff. 1984. RJ Reynolds. http://legacy library.ucsf.edu/tid/uhd95d00.

14. Philip Morris. Moist snuff growth spurred by smokers. 1989. Philip Morris. http:// legacy.library.ucsf.edu/tid/vea89a00.

15. Philip Morris. 1984. Smokeless tobacco. Philip Morris. http://legacy.library.ucsf.edu/ tid/hrx36e00.

16. British American Tobacco. Structured creativity conference. http://bat.library.ucsf edu/tid/hoi42a99.

17. RJ Reynolds. Project MARS. Hard tobacco. 2003. RJ Reynolds. http://legacy.library. ucsf.edu/tid/kim17a00.

18. Morgan Stanley Dean Witter. Adelman DJ. Tobacco: December Litigation Event Time Line P1. 16 Nov 2000. RJ Reynolds. http://legacy.library.ucsf.edu/tid/wtx46a00.

19. Morgan Stanley Dean Witter. Adelman DJ. UST: Review of Major Analyst Meeting P1. 17 Nov 2000. http://legacy.library.ucsf.edu/tid/rgb65a00.

20. Philip Morris. A qualitative exploration of snuff category. 1993. Philip Morris. http:// legacy.library.ucsf.edu/tid/ysc58a00.

21. Philip Morris. Snuff focus groups. 1993. Philip Morris. http://legacy.library.ucsf.edu/ tid/msu76e00.

22. Ferst SL, McMillin JM. Research UST Inc. Company report. 1992. Philip Morris http://legacy.library.ucsf.edu/tid/pgy57e00.

23. Moist smokeless tobacco (MST). Category business review. 2003. RJ Reynolds http://legacy.library.ucsf.edu/tid/age56a00.

24. Philip Morris. Select snuff. 1989. Philip Morris. http://legacy.library.ucsf.edu/tid/ pmc20b00.

25. Johnson Powell \& Co. RJ Reynolds Tobacco Company. Long-term new product development project status report. IV. Report. 1980. RJ Reynolds. http://legacy. library.ucsf.edu/tid/gdo49d00.

26. Lawson, JW. Asheville brainstorming session. 1984. RJ Reynolds. http://legacy library.ucsf.edu/tid/upl33a00. 
27. Introduction: A. Purpose and scope of the Mini-Lab was to find new ways to use microencapsulation. 1981. RJ Reynolds. http://legacy.library.ucsf.edu/tid/eal79d00.

28. RJ Reynolds. Question 1. What characteristics should a product have that make it appealing to consumers who desire. 1987. RJ Reynolds. http://legacy.library.ucsf. edu/tid/vgf43d00

29. Swaim MC. Gum base technology. 1981. RJ Reynolds. http://legacy.library.ucsf. edu/tid/vak77c00.

30. Johnson Powell \& Co. RJ Reynolds Tobacco Company Delphi \#II. 1980. RJ Reynolds. http://legacy.library.ucsf.edu/tid/bvx65d00.

31. RJ Reynolds. Specialty tobacco products strategic overview. 1984. RJ Reynolds. http://legacy.library.ucsf.edu/tid/fmv75d00.

32. RJ Reynolds. RJ Reynolds Tobacco Company 1985-1987 (850000-870000) Plan Action plan summary. 1984. RJ Reynolds. http://legacy.library.ucsf.edu/tid/vvp58d00

33. RJ Reynolds. 1983-1987 (830000-870000) Plan. 1982. RJ Reynolds. http://legacy library.ucsf.edu/tid/beu61d00.

34. Fackelman E, Hall LW Jr, Whitlatch WP, et al. Marketing development proposal (MDD\# 80-1057). WSH Package Test. 1980. RJ Reynolds. http://legacy.library.ucsf. edu/tid/nsk55a00.

35. Fackelman E, Keiser KJ, Novak G, et al. Marketing research proposal (MRD\# 80 1052). WSH Product Tests. 30 Jan 1980. RJ Reynolds. http://legacy.library.ucsf.edu/ tid/vkc55a00.

36. Curry AM, Wooten SC Jr. WSH Product Development. 9 April 1981. RJ Reynolds. http://legacy.library.ucsf.edu/tid/fbl75d00.

37. RJ Reynolds. Moist snuff production capacity summary discussion. 24 Nov 1980. RJ Reynolds. http://legacy.library.ucsf.edu/tid/ocu17a00.

38. Gemma JL, Albert M, Swaim MC, et al. Product research proposal. Product Guidance Test (Mdd \#82-31281). Wss (Wet Snuff-Skoal Type) \#2 Product Guidance Test. 31 Jan 1983. http://legacy.library.ucsf.edu/tid/hyi55a00.

39. Gemma JL, Albert M, Swaim, MC, et al. Phillips. Product research proposal. Product Guidance Test (Mdd \#82-31280). Wsc (Copenhagen Type Wet Snuff) \#2 Product Guidance Test. 31 Jan 1983. http://legacy.library.ucsf.edu/tid/xud95d00.
40. McBride C, Roubicek H, Brohman C. Project VISA. 1988. British American Tobacco http://bat.library.ucsf.edu/tid/jyr42a99.

41. Fackleman E. New brands and strategic research weekly status-August 8-12. 12 Aug 1983. RJ Reynolds. http://legacy.library.ucsf.edu/tid/ihj78d00.

42. RJ Reynolds. WSC and WSS. Positioning, name and copy strategy development. Jan 1983. RJ Reynolds. http://legacy.library.ucsf.edu/tid/qvg39d00.

43. RJ Reynolds. Winston marketing updated. 1984. RJ Reynolds. http://legacy.library ucsf.edu/tid/oso35d00.

44. Firy LS. Product research proposal (MDD \#84-31228). WSC product guidance test. 17 May 1984. http://legacy.library.ucsf.edu/tid/cmf38c00.

45. Lorillard. No title. 4 Oct 1978. Lorillard. http://legacy.library.ucsf.edu/tid/sox31e00

46. RJ Reynolds. Lenders presentation. 11 May 2006 (20060511). DRAFT - 5/9/06 (20060509). 9 May 2006. RJ Reynolds. http://legacy.library.ucsf.edu/tid/nml77a00.

47. AP Co. Introduces new tobacco product. 1 Aug 2001. Philip Morris. http://legacy. library.ucsf.edu/tid/utx41c00

48. Philip Morris. Update: new competitive tobacco-related technologies. 2001. Philip Morris. http://legacy.library.ucsf.edu/tid/lur38c00.

49. Philip Morris. Recent new products NPC 20010329. 29 Mar 2001. Philip Morris. http://legacy.library.ucsf.edu/tid/qcs91c00.

50. Philip Morris. Smokeless tobacco. 18 Aug 1989. Philip Morris. http://legacy.library. ucsf.edu/tid/omc20b00.

51. Philip Morris. US Tobacco Weekly 03-32 (7 August 2003). 26 Aug 2005. http:// legacy.library.ucsf.edu/tid/uoa17a00.

52. Hatsukami DK, Ebbert JO, Feuer RM, et al. Changing smokeless tobacco products new tobacco delivery systems. Am J Prev Med 2007;33(6S).

53. International Agency for Research on Cancer. Smokeless tobacco and some tobacco-specific N-nitrosamines. IARC Monographs on the Evaluation of Carcinogenic Risks to Humans. Volume 89, 2007. Available at: http://monographs.iarc.fr/ENG/ Monographs/vol89/mono89.pdf, accessed 24 June 2008.

54. Saloojee Y. South Africa: snus "not a tobacco product". Tob Control 2008;17:2-3.

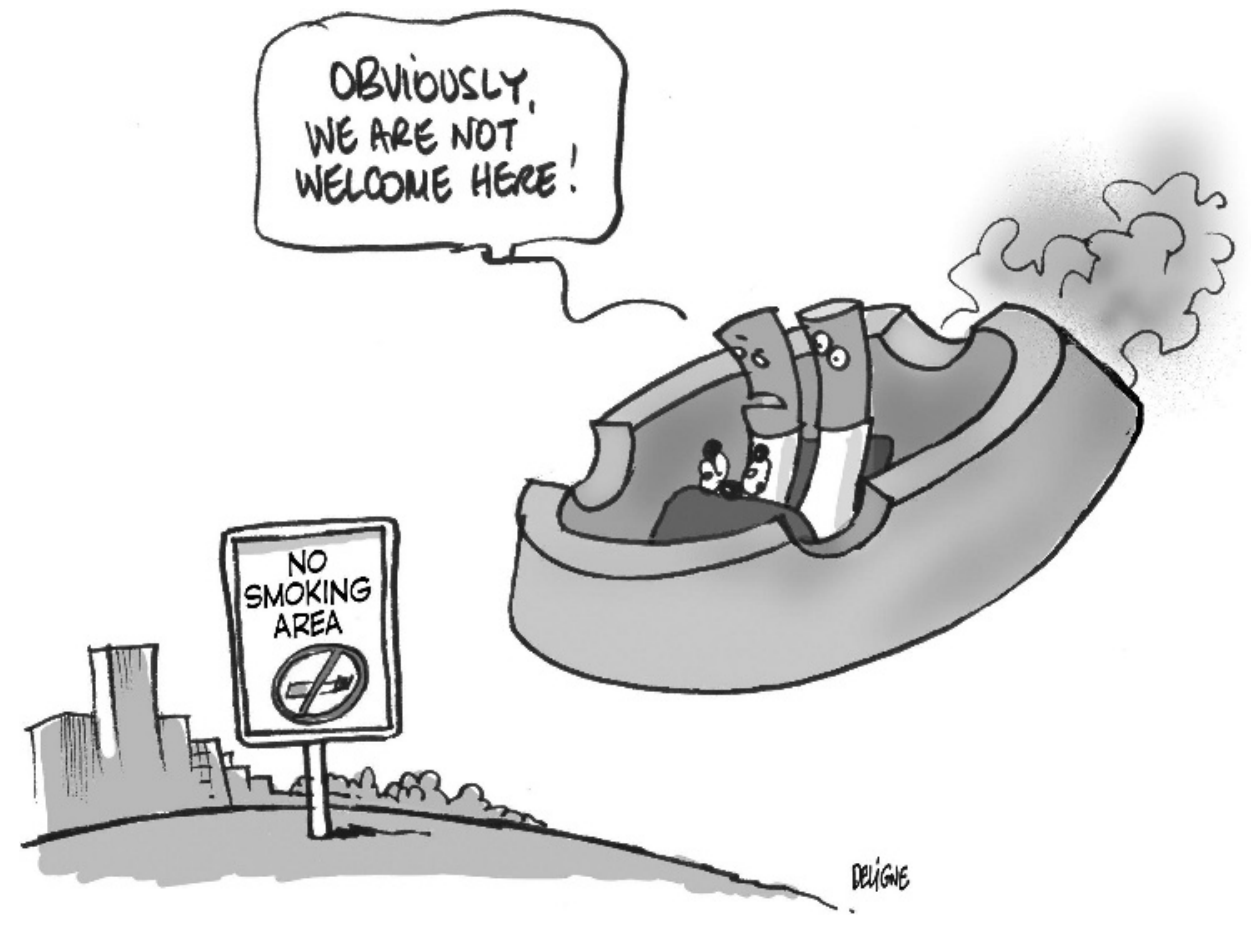

(c) Copyright 2007 Frederick Deligne. All rights reserved. 